UDK 632.9:633.15

Naučni rad - Scientific paper

\title{
Efficacy of PRE-EM herbicides in grass weed control in winter wheat (Triticum aestivum L.)
}

\author{
Zvonko Pacanoski \\ Faculty for Agricultural Sciences and Food, Ss. Cyril and Methodius University, \\ Skopje, R. Macedonia \\ e-mail: zvonko_lav@yahoo.com;zvonkop@fznh.ukim.edu.mk
}

\section{SUMMARY}

The field trials were conducted during two winter wheat growing seasons (2013-2014 and 2014-2015, respectively) to estimate grass weed control with pre-emergence (PRE-EM) premixes in winter wheat crop. Both sites were naturally infested with a high population of Avena ludoviciana Dur., Apera spica-venti (L.) P. Beauv., Milium vernale M. Bieb. and Alopecurus myosuroides Huds. The efficacy of pre-emergence (PRE-EM) herbicides varied among weed species, treatments, periods of efficacy estimation, regions and years, respectively. The overall performance of the PRE-EM herbicide premixes was correlated with the weather conditions. All PRE-EM herbicide premixes effectively reduced Apera spica-venti and Milium vernale at the Bitola region in 2013-2014, but not in 2014-2015, due to heavy rain $(68 \mathrm{~mm})$ during the $1^{\text {st }}$ and $2^{\text {nd }}$ week following the herbicide applications. Contrary to this, the limited precipitation after the PRE-EM application may have contributed to the poor performance of PRE-EM herbicides in controlling A. myosuroides in the Probištip region in 2013. Control of A. myosuroides improved in 2014-2015, because the Probištip region received enough precipitation to increase the efficacy of PRE-EM herbicide premixes. Twenty-eight DAA, all PRE-EM applied premixes controlled $A$. myosuroides between 92 and 100\%. The high efficacy in A. myosuroides control was also kept at 150 DAA. PRE-EM herbicide premixes controlled A. ludoviciana poorly (less than $69 \%$ and $63 \%$ in the Bitola region and no more than $49 \%$ and $67 \%$ in the Probištip region for both years, respectively), because of the ability of some seeds to germinate from greater depths, dormancy and multiple emerging flushes.

Keywords: PRE-EM herbicides, grass weeds, precipitations. 


\section{INTRODUCTION}

Winter wheat is the most sensitive to weed competition in its early stages of growth and especially in autumn sown crops (Pilipavičius, 2012), where grass weeds can be extremely competitive in the early stages (Tottman et al., 1982). They are becoming an increasingly important feature in Macedonian winter wheat farming. Grass weeds are generally more difficult to control in winter wheat and are relatively more competitive than broad-leaved weeds. There are a number of reasons why they are increasing, but perhaps the key factors are the increase of importance of winter wheat cropping, along with earlier sowing of wheat in the autumn, and also possible changes in the climate, with milder and more humid winters (Meiners, 2015). Grass weeds compete with crops for water, mineral nutrients, space and light (Gerhards and Massa, 2011). They are often very competitive as individual plants (Avena ludoviciana) or produce so much seeds that their populations rapidly increase to competitive levels (e.g. Alopecurus myosuroides, Apera spica-venti, Milium vernale).

A. ludoviciana emerges during mid-winter and infests major winter and spring crops, including winter wheat (Bajwa et al., 2017), causing losses of up to 35\% in wheat yield, mainly depending on weed density (Walia and Brar, 2001). Populations of 3 plants $\mathrm{m}^{-2}$ have been shown to reduce the yields of winter wheat up to $15 \%$, and 10 plants $/ \mathrm{m}^{2}$ reduced wheat yields by 30-40\% (Walia et al., 2001). A. ludoviciana has remarkable biological features, including high seed productivity, dormancy, which enables it to persist in seed banks for several years, vigorous growth, tall stature, extensive root system, phenotypic variation and the ability to germinate under a wide range of environmental conditions (Qasem, 2007; Owen and Powles, 2009; Beckie et al., 2012). For these reasons, this weed species is very difficult to control and maintain below acceptable economic thresholds.

A. myosuroides is a predominant annual winter grass weed (Moss, 2013), which is well adapted to agricultural production systems, which include early sowing dates, non-ploughing cultivations, high nitrogen levels and crop rotations dominated by winter cereals (Knab and Hurle, 1988; Amann, 1991; Hurle, 1993). Due to its well-adapted growth behavior in winter cereals, A. myosuroides can be very competitive (Moss, 1985; Amann et al., 1992; Melander, 1995). Even at low densities black-grass can cause significant yield losses. Populations as low as 12 plants $\mathrm{m}^{-2}$ have been shown to reduce winter wheat yields in England by between $<5$ and $15 \%$ on average, while yield losses of $400-800 \mathrm{~kg}$ wheat ha- $\mathrm{c}^{-1}$ can be expected with $A$. myosuroides populations of 12-25 plants $\mathrm{m}^{-2}$, and much higher losses of over $2000 \mathrm{~kg}$ wheat $\mathrm{ha}^{-1}$ at densities of over 100 plants $\mathrm{m}^{-2}$ (Moss, 2013).

A. spica-venti and M. vernale are winter annual grass weeds with a winter growth habit and present an increasingly severe weed problem in autumn-sown crops. They are the most prevalent and important weeds of winter cereals, particularly wheat and barley in many European countries (Hamouzová et al., 2014; Luneva and Budrevskaya, 2016), including the Republic of Macedonia (Pacanoski, 2003). A. spica-venti causes yield losses exceeding those inflicted by A. myosuroides (Melander, 1995), resulting in even greater incentive for effective control. In the ranking of the 15 most important weed species found in winter cereal 
crop systems in 26 European countries, A. spica-venti was ranked fifth among all weeds and first among grasses (Schroeder et al., 1993). Polish researchers have estimated the economic threshold level for winter wheat to be about 10-20 plants $\mathrm{m}^{-2}$ (Rola and Rola, 1983), which $A$. spica-venti easily exceeds (Northam and Callihan, 1992). Bartels (2004) found a grain yield loss of $3 \mathrm{t} \mathrm{ha}^{-1}$ in untreated plots which were infested with $200 \mathrm{~A}$. spica-venti plants $\mathrm{m}^{-2}$ and according to Melander et al. (2008) it reduced wheat yields between 10 and 30 percent, in spite of the control efforts.

Because the emergence and growth of winter grass weeds closely coincides with winter wheat, autumn herbicide application can control weeds which survive the winter period and affect the winter wheat growth, thus providing better conditions for crop competition when vegetative growth begins in the spring (Pilipavičius et al., 2010). Also, the importance of herbicides with residual activity to cover the prolonged period of weed emergence becomes obvious in years with mild winters and a high level of seed dormancy.

For this purpose, some "forgotten" and "old" well-known herbicide active ingredients are again in the game. Among them, pendimethalin, isoproturon, chlortoluron and isoxaben are the most frequently applied in different combinations. Maraton 375 SC (isoproturon + pendimethalin) (Szelezniak et al., 2007; Weber et al., 2014) and Aubaine (isoxaben + chlortoluron) (Citron et al., 2006) are premixes recently registered for PRE-EM weed control in winter wheat.

These herbicides are lipophilic, with a $\log K_{o w}$ of 5.18 for pendimethalin (Đurović et al., 2008), 3.94 for isoxaben (Tomlin, 2003) and 2.5 for chlortoluron and isoproturon, respectively (El Gouzi et al., 2012). This chemical property is associated with a strong organic soil adsorption which results in limited soil mobility (Chandran, and Derr, 1999; Barba et al., 2003). Soil residual activity may be maintained for 16-(chlortluron) (Tomlin, 2003) for up to 20-25 weeks (pendimethalin, izoxaben and isoproturon) (Vouzounis and Americanos, 1995; Chandran, 1997; Alletto et al., 2006), thus ensuring the long lasting weed control and covering the prolonged period of weed emergence.

Taking into account the fact that soil-residual PRE herbicides can decrease and delay susceptible annual grass weed emergence and establishment, reduce subsequent growth and minimize weed/crop interactions (Adcock and Banks, 1991; Black and Dyson, 1993), our main objectives were to determine whether acceptable weed control of PRE premixes in winter wheat crop can reduce the selection pressure on subsequent POST herbicide applications and remove much of the early season weed competitive pressure on a crop by controlling the grass weeds which emerge with winter wheat.

\section{MATERIAL AND METHODS}

The field trials were conducted during two winter wheat growing seasons in 2013-2014 and 2014-2015 on commercial wheat fields at the Bitola and Probištip wheat-growing regions, in south-western and north-eastern part of Macedonia. The soil at the Bitola region was a 
Molic-vertic gleysol cumuligleyic vertisol with $27.10 \%$ coarse, $47.30 \%$ fine sand, $25.60 \%$ clay+silt, $1.86 \%$ organic matter and $\mathrm{pH}$ of 6.3 . The soil at the Probištip region was a vertisol with $3.5 \%$ coarse, $9.1 \%$ coarse sand, $30.0 \%$ sand, $60.3 \%$ silt+clay, $2.4 \%$ organic matter and $\mathrm{pH}$ of 7.2 (Filipovski, 2006). The wheat was grown following conventional tillage practices. The soil was tilled with a field cultivator prior to sowing. Nitrogen, phosphorus and potassium were applied as recommended by soil test results. The field trials were carried out with "Ingenio" and "Pobeda" winter wheat cultivars which were sowed in a well-prepared seedbed at a seeding rate of 220 and $240 \mathrm{~kg} \mathrm{ha}^{-1}$ on October $10^{\text {th }}, 2013$ and October $18^{\text {th }}, 2014$, at Bitola region, and on October $12^{\text {th }}, 2013$ and October $21^{\text {st }}, 2014$, at the Probištip region, respectively. The trials were conducted in different sites of the same commercial wheat fields. Herbicides were applied with a $\mathrm{CO}_{2}$-pressurized backpack sprayer calibrated to deliver $300 \mathrm{l} \mathrm{ha}^{-1}$ of aqueous solution at $220 \mathrm{kPa}$. Herbicides were applied at dry seeds - at the beginning of seed imbibition wheat growing stage (BBCH 00-01). Weeds at the time of treatment were in the same growth stage as the wheat (BBCH 00-01). The experimental design was a randomized complete block with four replicates. The following treatments were included in the study (Table 1).

Table 1. Treatments, active ingredients and rates of herbicides

Tabela 1. Tretmani, aktivne supstance i količina primene herbicida

\begin{tabular}{|c|c|c|c|}
\hline $\begin{array}{l}\text { Treatment } \\
\text { Tretman }\end{array}$ & $\begin{array}{l}\text { Active ingredient } \\
\text { Aktivna supstanca }\end{array}$ & $\begin{array}{l}\text { Company producer } \\
\text { Preparat }\end{array}$ & $\begin{array}{l}\text { Rate } \\
\text { Količina primene }\end{array}$ \\
\hline Untreated control & - & - & - \\
\hline Aubaine & $\begin{array}{l}\text { chlortoluron } 500 \mathrm{gl}^{-1}+\text { isoxaben } \\
18.7 \mathrm{~g} \mathrm{l}^{-1}\end{array}$ & Dow AgroScience LLC, Indianapolis, IN & $3.61 \mathrm{ha}^{-1}$ \\
\hline Maraton 375 SC & $\begin{array}{l}\text { pendimethalin } 250 \mathrm{~g} \mathrm{l}^{-1}+ \\
\text { isoproturon } 125 \mathrm{~g} \mathrm{l}^{-1}\end{array}$ & BASF, Ludwigshafen am Rhein, Germany & $4.0 \mathrm{l} \mathrm{ha}^{-1}$ \\
\hline $\begin{array}{l}\text { Tolurex } 50 \mathrm{SC}+ \\
\text { Logran } 75 \mathrm{WG}\end{array}$ & $\begin{array}{l}\text { chlortoluron } 500 \mathrm{~g} \mathrm{l}^{-1}+ \\
\text { triasulfuron } 750 \mathrm{~g} \mathrm{~kg}^{-1}\end{array}$ & $\begin{array}{l}\text { Makhteshim Agan Industries Ltd., Omer, Israel; } \\
\text { Syngenta International, Basel, Switzerland }\end{array}$ & $\begin{array}{l}3.21 \mathrm{ha}^{-1}+0.037 \\
\mathrm{~kg} \mathrm{ha}^{-1}\end{array}$ \\
\hline Quartz Super & $\begin{array}{l}\text { diflufenican } 50 \mathrm{~g} \mathrm{l}^{-1}+\text { isoprotu- } \\
\text { ron } 500 \mathrm{~g} \mathrm{l}^{-1}\end{array}$ & Globachem NV Sint-Truiden, Belgium & $1.61 \mathrm{ha}^{-1}$ \\
\hline
\end{tabular}

Weed control efficacy was estimated 28 days after application (DAA) (the first estimation) and in the spring, 150 DAA in the middle of the wheat tillering stage (BBCH 24-26) (the second estimation), by counting the weed plants from a $1 \mathrm{~m}^{2}$ area within each plot.

Total weekly rainfalls, as well as weekly average temperatures 1 week before and 4 weeks after PRE applications were recorded (Table 2). Precipitations 1 week before and 4 weeks after PRE applications in 2013 were in line with the average values for the Bitola region, but scarce for the Probištip region. In Bitola region the precipitation occurred during the $2^{\text {nd }}$ day of the week before PRE applications, and first 2 and the last 1 day of $1^{\text {st }}$ and the last 2 days of $3^{\text {rd }}$ week after PRE applications, respectively. Contrary to this, in the Probištip region during the same year, it rained on 7 and 11 days at intervals throughout the period of 1 week before and 4 weeks after the PRE application, respectively. The 4 week period after PRE application in the autumn of 2014 in Bitola region was unusually wet, particularly the $2^{\text {nd }}, 3^{\text {rd }}$, and $4^{\text {th }}$ day of the $1^{\text {st }}$ week, as well as 3 days in the middle of the $2^{\text {nd }}$ and the last 2 days of $4^{\text {th }}$ week, 
respectively. This period was very humid - 56\% above the 30ys average for the Bitola region $(106 \mathrm{~mm})$. There was no precipitation 1 week before the PRE applications. However, the precipitation which occurred in the $1^{\text {st }}, 2^{\text {nd }}$, and $4^{\text {th }}$ week after the PRE application, as well as during the $1^{\text {st }}$ week before the PRE applications in the Probištip region for the same year were in line with the average for this region $(11,13,8$, and $14 \mathrm{~mm})$. The $3^{\text {rd }}$ week was wetter when compared with the previous ones $(23 \mathrm{~mm}$ ) (Table 2).

1 week before and 4 weeks after the PRE applications, temperatures for both years and regions were a little bit above the average and that was attributed to favourable environmental conditions associated with non frost night time during the estimated 1 and 4 week period before and after PRE applications, respectively. PRE treatments in both years were applied at times when herbicide applications typically occur in Macedonia wheat production (Table 2) and are thus representative of the producer practices and label recommendations.

The data were tested for homogeneity of variance and normality of distribution (Ramsey and Schafer, 1997) and were log-transformed as needed to obtain the roughly equal variances and better symmetry before ANOVA was performed. The data were transformed back to their original scale for presentation. The means were separated by using the LSD test at 5\% of probability.

Table 2. Mean weekly temperatures and total weekly rainfall 1 week before and 4 weeks after PRE applications, respectively at Bitolj and Probištip region in 2013 and 2014

Tabela 2. Srednje nedeljne temperature i ukupne nedeljne količine padavina pre i četiri nedelje posle PRE-EM primene herbicida, za Bitolj i Probištip u 2013. i 2014. godini

\begin{tabular}{lcccccccc}
\hline & \multicolumn{3}{c}{ Bitolj region / Područje Bitolja } & \multicolumn{2}{c}{ Probištip region / Područje Probištipa } \\
\hline Weeks & \multicolumn{2}{c}{$\mathbf{2 0 1 3}$} & $\mathrm{2014}$ & \multicolumn{2}{c}{$\mathbf{2 0 1 3}$} & \multicolumn{2}{c}{$\mathbf{2 0 1 4}$} \\
$1^{\text {st }}$ WBA & $\mathrm{P}(\mathrm{mm})$ & $\mathrm{T}\left({ }^{\circ} \mathrm{C}\right)$ & $\mathrm{P}(\mathrm{mm})$ & $\mathrm{T}\left({ }^{\circ} \mathrm{C}\right)$ & $\mathrm{P}(\mathrm{mm})$ & $\mathrm{T}\left({ }^{\circ} \mathrm{C}\right)$ & $\mathrm{P}(\mathrm{mm})$ & $\mathrm{T}\left({ }^{\circ} \mathrm{C}\right)$ \\
$1^{\text {st }}$ WAA & 14 & 13 & 0 & 15 & 5 & 15 & 11 & 17 \\
$2^{\text {nd }}$ WAA & 10 & 9 & 37 & 10 & 7 & 10 & 13 & 14 \\
$3^{\text {rd }}$ WAA & 21 & 8 & 31 & 7 & 2 & 14 & 9 & 11 \\
$4^{\text {th }}$ WAA & 6 & 6 & 27 & 7 & 11 & 9 & 14 & 9 \\
\hline
\end{tabular}

WBA, week before application; WAA, week after application; P, precipitations, T-temperature

\section{RESULTS AND DISCUSSION}

Weed population. Both sites were naturally infested with dense populations of Avena ludoviciana Dur., Apera spica-venti (L.) P. Beauv., Milium vernale M. Bieb. and Alopecurus myosuroides Huds. Broad-leaved weed infestations were light throughout both experimental years. Weed density in nontreated control plot was 93 and 135 plants $\mathrm{m}^{-2}$ in 2013-2014 and

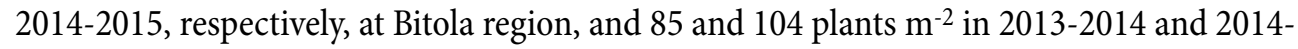
2015, respectively, at Probištip region. 
Weed control. The efficacy of PRE herbicides varied among weed species, treatments, periods of efficacy assessment, regions and years, respectively. The overall performance of the PRE-EM herbicide premixes were correlated with the weather conditions. Inconsistent weather patterns between the 2 years of the study likely influenced the weed control. Humid autumn in 2014 (Table 2), with a particularly heavy rain $(68 \mathrm{~mm})$ during the $1^{\text {st }}$ and $2^{\text {nd }}$ week of the herbicide applications and before the weed emergence, was probably the most likely reason for the leaching of herbicides from soil surface and lower efficacy of PRE-EM applied premixes in 2014, when compared to their application in 2013 in the Bitola region (Table 3). Contrary, the limited precipitation after the PRE-EM application may have contributed to the poor performance of PRE-EM herbicides in the Probištip region in 2013, when compared to 2014 (Table 4).

Table 3. Avena ludoviciana control 28 and 150 days after PRE herbicide applications, in winter wheat in 2013-2014 and 2014-2015 in Bitolj and Probištip region

Tabela 3. Efekti PRE-EM primene herbicida na Avena ludoviciana 28 i 150 dana nakon tretiranja u usevu ozime pšenice u 2013-2014. i 2014-2015. godini, Bitolj i Probištip

\begin{tabular}{|c|c|c|c|c|c|c|c|c|c|}
\hline \multirow{3}{*}{$\begin{array}{l}\text { Treatments } \\
\text { Tretman }\end{array}$} & \multirow{3}{*}{$\begin{array}{l}\text { Rate } \\
\text { Količina } \\
\text { primene } \\
\left(\mathrm{g} ; 1 \mathrm{ha}^{-1}\right)\end{array}$} & \multicolumn{4}{|c|}{$\begin{array}{c}\text { Bitolj region } \\
\text { Područje Bitolja }\end{array}$} & \multicolumn{4}{|c|}{$\begin{array}{c}\text { Probištip region } \\
\text { Područje Probištipa }\end{array}$} \\
\hline & & \multicolumn{2}{|c|}{ 2013-2014 } & \multicolumn{2}{|c|}{ 2014-2015 } & \multicolumn{2}{|c|}{ 2013-2014 } & \multicolumn{2}{|c|}{ 2014-2015 } \\
\hline & & $\begin{array}{c}28 \\
\text { DAA } \\
\end{array}$ & $\begin{array}{r}150 \\
\text { DAA }\end{array}$ & $\begin{array}{c}28 \\
\text { DAA }\end{array}$ & $\begin{array}{c}150 \\
\text { DAA }\end{array}$ & $\begin{array}{c}28 \\
\text { DAA }\end{array}$ & $\begin{array}{r}150 \\
\text { DAA }\end{array}$ & $\begin{array}{c}28 \\
\text { DAA } \\
\end{array}$ & $\begin{array}{r}150 \\
\text { DAA }\end{array}$ \\
\hline Weedy control & - & 0 & 0 & 0 & 0 & 0 & 0 & 0 & 0 \\
\hline Aubaine & 3.6 & $58^{\mathrm{b}}$ & $55^{\mathrm{a}}$ & $63^{\mathrm{a}}$ & $58^{\mathrm{a}}$ & $44^{\mathrm{a}}$ & $47^{\mathrm{a}}$ & $61^{\mathrm{ab}}$ & $63^{\mathrm{a}}$ \\
\hline Maraton 375 SC & 4.0 & $54^{\mathrm{b}}$ & $57 \mathrm{a}$ & $59 \mathrm{ab}$ & $53^{\mathrm{a}}$ & $49^{a}$ & $41^{\mathrm{a}}$ & $59^{\mathrm{ab}}$ & $64^{\mathrm{a}}$ \\
\hline Tolurex + Logran & $3.2+0.037$ & $67^{\mathrm{a}}$ & $63^{\mathrm{a}}$ & $55^{\mathrm{b}}$ & $52^{\mathrm{a}}$ & $37^{b}$ & $43^{\mathrm{a}}$ & $67^{a}$ & $62^{\mathrm{a}}$ \\
\hline Quartz Super & 1.6 & $69^{\mathrm{a}}$ & $59^{a}$ & $63^{\mathrm{a}}$ & $54^{\mathrm{a}}$ & $28^{c}$ & $25^{\mathrm{b}}$ & $55^{\mathrm{b}}$ & $53^{\mathrm{b}}$ \\
\hline LSD 0.05 & & 5.89 & 9.08 & 6.09 & 8.81 & 6.52 & 7.19 & 8.56 & 7.72 \\
\hline $\begin{array}{l}\text { Random effect interactions } \\
\text { PRE herbicides treatment } x \text { year }\end{array}$ & & \multicolumn{4}{|c|}{ NS } & \multicolumn{4}{|c|}{ NS } \\
\hline PRE herbicides treatment $x$ PEE & & \multicolumn{2}{|c|}{ NS } & \multicolumn{2}{|c|}{ NS } & \multicolumn{2}{|c|}{ NS } & \multicolumn{2}{|c|}{ NS } \\
\hline
\end{tabular}

PEE- periods of efficacy estimation; NS-not significant; ${ }^{*}$ Significant at the $5 \%$ level according to a Fisher's protected LSD test at $\mathrm{P}<0.05$.

Avena ludoviciana. A. ludoviciana control did not differ among regions, years, and periods of efficacy assessment for PRE-EM herbicide premixes. PRE-EM herbicides, regardless of the year had a very poor effect on A. ludoviciana in both regions. In the Bitola region in 20132014, the control of A. ludoviciana was less than $69 \%$ and $63 \%$ with any PRE-EM treatment 28 DAA and 150 DAA, respectively. Similar efficacy ( $<63 \%$ and $<58 \%$, respectively) was recorded in 2014-2015. In the Probištip region PRE-EM herbicide premixes provided no more than 49\% and 67\% control of A. ludoviciana in 2013-2014 and 2014-2015, respectively (Table 3). In general, pre-emergence herbicides do not control A. ludoviciana effectively (Thomas and Yaduraju, 2000), because of the ability of its seeds to germinate from greater soil depths (under certain conditions from depths as great as $25 \mathrm{~cm}$ ) (Kostov, 2006) and stay dormant in soil 


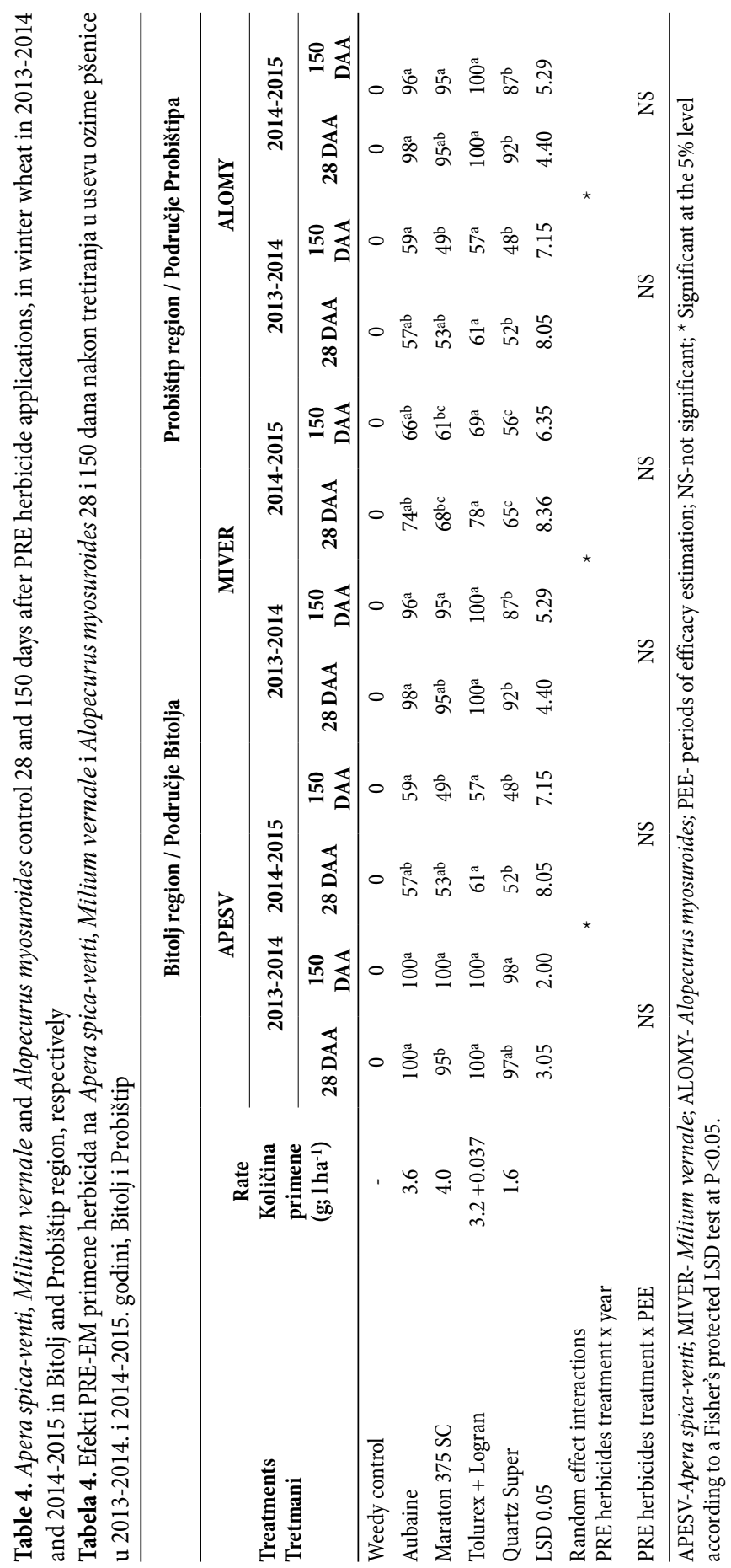


(Sharma and Vanden Born, 1978; Smit, 1993; Wu and Koetz, 2014). Dormancy and multiple emerging flushes throughout the growing season result in the persistence and continual reinfestation of this weed in the soil seed bank (Fuerst et al., 2011; Beckie et al., 2012). Poor wild oat control and, at same time, the highest dry weights of this weed $\left(9.43,8.70\right.$ and $\left.8.16 \mathrm{~g} \mathrm{~m}^{-2}\right)$ were recorded in plots treated with isoproturon at $1.5 \mathrm{~kg}$ ai ha-1, isoproturon + diflufenicon at $0.98 \mathrm{~kg}$ ai ha-1, isoproturon + carfentrazone ethyl at $2.0 \mathrm{~kg}^{-1}$ ai ha-1, respectively (Shehzad et al., 2012). Contrary to this, Singh and Gosh (1992) have reported that the application of pendimethalin and isoproturon before emergence provided a maximum control of $A$. ludoviciana.

Apera spica-venti. A significant interaction in treatments by year resulted in two distinct years for A. spica-venti control in the Bitola region with PRE-EM herbicide premixes. A. spica-venti control did not differ between periods of efficacy estimated by year. In 2013-2014 all investigated PRE premixes provided more than $95 \%$ control of $A$. spica-venti for both estimated periods of efficacy. The control decreased drastically the following year, because the Bitola region received $68 \mathrm{~mm}$ of precipitation in the $1^{\text {st }}$ and $2^{\text {nd }}$ week of herbicide application. It is likely that these extreme humid conditions contributed to the reduced efficacy of PRE herbicides, which ranged between 57 and $67 \%$ (Table 4). In the autumn application, flufenacet-containing herbicides, such as Malibu (flufenacet + pendimethalin), Herold SC (flufenacet + diflufenican), Bacara Forte (flufenacet, + flurtamone + diflufenican), as well as Carmina 640 (chlortoluron + diflufenican) and Fenikan (isoproturon + diflufenican) demonstrated a high efficiency against $A$. spica-venti (Schröder et al., 2012). Herbicide premixes isoproturon $500 \mathrm{~g} \mathrm{l}^{-1}+$ diflifenican $100 \mathrm{~g} \mathrm{l}^{-1}$, and chlortoluron $79.25 \%$ + triasulfuron $0.75 \%$ controlled A. spica-venti very effectively (91\%) (Manea et al., 2009). Similarly, Stankiewicz-Kosyl et al. (2017) have stated that the most effective herbicide premix in the control of Apera spica-venti was isoproturon + hlortosulfuron.

Milium vernale. A significant interaction in treatments by year resulted in two distinct years for M. vernale control in the Bitola region with PRE herbicides, but M. vernale control did not differ between periods of efficacy estimated by year. In this region in 2013-2014, 28 DAA, all of the PRE-EM applied premixes controlled M. vernale between 87 and 100\%. However, the excellent control (>95\%) was achieved with Aubaine and Tolurex + Logran. Negligibly lower M. vernale control was obtained 150 DAA. The efficacy of all PRE applied premixes ranged between $82 \%$ and $96 \%$ (Table 4). This was probably due to the residual activity of PRE herbicides and no new spring growth of M. vernale, because it is a typical winter weed (Kostov, 2006). Contrary to this, all PRE-EM herbicide premixes provided unsatisfactory control of $M$. vernale in 2014-2015. Regardless of the period of efficacy assessment, the herbicides controlled M. vernale between 58 and 78\% (Table 4). The differences in control of $M$. vernale between the years demonstrated that higher amounts of precipitation $(37 \mathrm{~mm})$ after herbicide application in 2014-2015 caused herbicides to leach through the soil profile and consequently decreased the weed control efficacy (Ferrell et al., 2004; Tanji and Boutfirass, 2018).

Alopecurus myosuroides. A significant interaction in treatments by year resulted in two distinct years for A. myosuroides control in the Probištip region with PRE-EM herbicides. 
However, $A$. myosuroides control did not differ between periods of efficacy assessment by year. In 2013-2014, PRE herbicides provided control of $A$. myosuroides between 52 and 61\% (28 DAA), and 48 and 59\% (150 DAA). The lack of effective control of $A$. myosuroides can be attributed to the low rainfall amounts after the PRE application in 2013 (Table 2). Since many of the PRE herbicides can volatilize and photodegrade on the soil surface over time, rainfall is needed to move these herbicides into the zone where weed seeds germinate (Wilcut et al., 1994; Janak and Grichar, 2016) which explains the inconsistent control of $A$. myosuroides documented with PRE herbicide premixes under the drought conditions observed at the Probištip region in autumn of 2014. The control of A. myosuroides improved in 2014-2015, because the Probištip region received enough precipitation $\left(11 \mathrm{~mm}^{\text {st }} \mathrm{WBA}\right.$ and $13 \mathrm{~mm}^{\text {st }}$ WAA, respectively) to increase the efficacy of PRE herbicide premixes. 28 DAA, all PRE-EM applied premixes controlled $A$. myosuroides between 92 and 100\% (Table 4). The high efficacy in A. myosuroides control was kept even 150 DAA, because A. myosuroides shares the same growth cycle as the autumn-sowed wheat (Orson and Thomas, 2001), meaning that it is a typical winter weed (Kostov, 2006) and no new spring growth was recorded. Quartz Super provided at least $87 \%$ control of A. myosuroides, while Maraton 375 SC Aubaine, and Tolurex + Logran provided a better control than Quartz Super (95-100\%) (Table 3). Single application of isoproturon or chlorotoluron used in the U.K. resulted in a very effective control of $A$. myosuroides (Orson and Harris, 1997). According to Moss et al. (2009) PRE-EM flufenacet + pendimethalin $\left(240+1200 \mathrm{~g}^{2}\right.$ ai ha- $\left.{ }^{-1}\right)$ gave $93 \%$, and PRE-EM flufenacet+pendimethalin followed by isoproturon + pendimethalin $(1500+1320 \mathrm{~g}$ ai ha ${ }^{-1}$ ) achieved a $97 \%$ reduction of $A$. myosuroides.

\section{CONCLUSION}

The results of this work have demonstrated that the efficacy of PRE-EM herbicides in wheat crop are strongly dependent on the amount of precipitation and weed grass population. Humid autumn in 2014, with particularly heavy rainfall during the $1^{\text {st }}$ and $2^{\text {nd }}$ week of herbicide application, was probably the most likely reason for the leaching of herbicides from the soil surface and lower efficacy of PRE-EM applied premixes in 2014, when compared to their application in 2013 in the Bitola region. Therefore, Aubaine, Maraton 375 SC, Tolurex + Logran, and Quartz Super effectively reduced dominant M. vernale, and A. spica-venti in 2013-2014, but not in 2014-2015. Contrary to this, in the Probištip region in 2013, the limited precipitation 7 days before and after herbicide application reduced the efficacy of PRE-EM herbicides which require precipitation for optimal activity and control of grass weeds. Dry or very humid environmental and soil conditions immediately after the PRE-EM autumn herbicide application accompanied by poor control of $A$. ludoviciana germinating from greater depths indicate that any combination of PRE-EM herbicides may need to be followed by POST-EM herbicides for the control of escaped and newly emerged grass weeds. Therefore, the precipitation amount and grass weed flora should be considered when selecting the most appropriate PRE-EM weed management strategy in the winter wheat crop. 


\section{LITERATURE}

Adcock, T. E., Banks, P.: Effects of preemergence herbicides on competitiveness of selected weeds. Weed Science, 39, 54-56, 1991.

Alletto, L., Coquet, Y., Benoit, P., Bergheaud, V.: Effects of temperature and water content on degradation of isoproturon in three soil profiles. Chemosphere, 64 (7), 1053-1061, 2006.

Amann, A.: Einfluss von Saattermin und Grundbodenbearbeitung auf die Verunkrautung in verschiedenen Kulturen. Dissertation, University Hohenheim, 1991.

Amann, A., Zwerger, P., Hurle, K.: Einfluss von Saattermin und Grundbodenbearbeitung auf die Populationsdynamik von Alopecurus myosuroides Huds. in verschiedenen Kulturen. Z. Pfl. Krankh. PflSchutz, Sonderheft XIII, 269-276, 1992.

Bajwa, A. A., Akhter, M. J., Iqbal, N., Peerzada, A. M., Hanif, Z., Manalil, S., Hashim, S., Ali, H. H., Kebaso, L., Frimpong, D., Namubiru, H., Chauhan B. S.: Biology and management of Avena fatua and Avena ludoviciana: two noxious weed species of agro-ecosystems. Environmental Science and Pollution Research, 24, 19465-19479, 2017.

Barba, A., Oliva, J., Garcsia, M. A., Rubio, A.: Leaching of benfluralin, pendimethalin and propyzamide in different soil types. An experinmental approach. In the Proceedings of the XII Symposium Pesticide Chemistry, June 4-6, Piacenza, Italy, 299-308, 2003.

Bartels, M.: Ungräser sollten Sie im Herbst beseitigen. Top Agrar, 9, 50-55, 2004.

Beckie, H. J., Francis, A., Hall, L. M.: The biology of Canadian weeds. 27. Avena fatua L. (updated). Canadian Journal of Plant Science, 92 (7), 1329-1356, 2012.

Black, I. D., Dyson, C. B.: An economic threshold model for spraying herbicides in cereals. Weed Research, 33, 279-290, 1993.

Chandran, R. S.: Influence of isoxaben application timing on dissipation and broadleaf weed control in turf. Doctoral Dissertation, Faculty of the Virginia Polytechnic, Institute and State University, Blacksburg, Virginia, 1997.

Chandran, R. S., Derr, J. F.: Isoxaben dissipation in field soil as affected by application timing: Journal of Environmental Quality, 28 (6), 1760-1764, 1999.

Citron, G., Réal, B., Bousquet, N.: Les herbicides racinaires. Perspectives Agricoles, $\mathrm{N}^{\circ} 327$. https://www. perspectivesagricoles.com/file/galleryelement/pj/f1/cc/bb/27/327_2412986240080970196.pdf, 2006

Đurović, R., Gajić Umiljendić, J., Đorđević, T.: Determination of atrazine, acetochlor, clomazone, pendimethalin and oxyfluorfen in soil by a solid phase microextraction method. Pesticide and Phytomedicina, 23, 265-271, 2008.

El Gouzi, S., Mingorance, M. D., Draoui, K., Chtoun, E. H., Peña, A.: Mobility of isoproturon and chlortoluron in soil columns irrigated with wastewater. In the Proceedings of the $1^{\text {st }}$ International Congress and Fair on Water, Waste and Energy Management, 2012.

Ferrell, M. A., Whitson, T. D., Miller, S. D.: Basic guide to weeds and herbicides. The University of Wyoming, College of Agriculture, Department of Plant Sciences, Cooperative Extension Service, MP18, pp. 1-19, 2004.

Filipovski, G.: Soil classification of the Republic of Macedonia", MASA, 313-323, 2006.

Fuerst, E. P., Anderson, J. V., Kennedy, A. C., Gallagher, R. S.: Induction of polyphenol oxidase activity in dormant wild oat (Avena fatua) seeds and caryopses: a defense response to seed decay fungi. Weed Science, 59 (2), 137-144, 2011.

Gerhards, R., Massa, D.: Two-year investigations on herbicide-resistant silky bent grass (Apera spica-venti $\mathrm{L}$. Beauv.) populations in winter wheat-population dynamics, yield losses, control efficacy and introgression into sensitive population. Gesunde Pflanzen, 63 (2), 75-82, 2011.

Hamouzová, K., Košnarová, P., Salava, J., Soukup, J., Hamouz, P.: Mechanisms of resistance to acetolact ate synthase-inhibiting herbicides in populations of Apera spica-venti from the Czech Republic. Pest Management Science, 70 (4), 541-548, 2014. 
Hurle, K.: Integrated management of grass weeds in arable crops. In: Proceedings 1993 Brighton Crop Protection Conference - Weeds, Brighton, UK, pp. 81-88, 1993.

Janak, T. W., Grichar, W. J.: Weed control in corn (Zea mays L.) as influenced by preemergence herbicides. International Journal of Agronomy, Article ID 2607671, 9 pages,. doi:10.1155/2016/2607671, 2016.

Knab, W., Hurle, K.: Einfluss der Grundbodenbearbeitung auf Ackerfuchsschwanz (Alopecurus myosuroides Huds.). Z. Pfl. Krankh. PflSchutz, Sonderheft XI, 97-108, 1988.

Kostov, T.: Herbology. Scientific Book. The University Press of the Republic of Macedonia, Skopje. 371pp, 2006.

Luneva, N. N., Budrevskaya, I. A.: Apera spica-venti (L). Beauv. Silky bentgrass, wind-grass. Agro Atlas. Last accessed August 11, http://www.agroatlas.ru /en/content/weeds/Apera_spica-venti/index.html, 2016.

Manea, D. N., Arsene, G., Cârciu, G., Alda, S.: Apera spica venti: A problem weed in straw cereals in the Banat Hill area. Research Journal of Agricultural Science, 41 (1), 245-250, 2009.

Meiners, I.: Management of black-grass (Alopecurus myosuroides Huds.) in winter wheat and taking into account the soil activity of post-emergence herbicides. Inaugural Dissertation. Faculty of Agricultural and Nutritional Sciences, and Environmental Management of the Justus Liebig University Giessen, Germany, 2015.

Melander, B., Holst, N., Jensen, P., Hansen, E., Olesen, J.: Apera spica-venti population dynamics and impact on crop yield as affected by tillage, crop rotation, location and herbicide programmes. Weed Research, 48, 48-57, 2008.

Melander, B.: Impact of drilling date on Apera spica-venti L. and Alopecurus myosuroides Huds. in winter cereals. Weed Research, 35, 157-166, 1995.

Moss, S. R.: The survival of Alopecurus myosuroides Huds. seeds in soil. Weed Research, 25, 201-211, 1985.

Moss, S. R., Hull, R., Marshall, R.: Control of Alopecurus myosuroides (black-grass) resistant to mesosulfuron+iodosulfuron. Communication in Agricultural and Applied Biological Sciences, 74 (2), 479-88, 2009.

Moss, S. R.: Black-grass (Alopecurus myosuroides): Everything you really wanted to know about black-grass but didn't know who to ask. Revised 2013. Rothamsted technical publication, 2013.

Northam, F. E., Callihan, R. H.: The windgrasses (Apera Adans., Poaceae) in North America. Weed Technology, 6, 445-450, 1992.

Orson, J. H., Harris, D.: Technical and financial impact of herbicide resistant Blackgrass (Alopecurus myosuroides) on individual farm businesses in England. The 1997 Brighton Crop Protection Conference - Weeds, 1997.

Orson, J. H., Thomas, M. R.: Impact of generic herbicides on current and future weed problems and crop management. In the Proceedings of the Brighton Crop Protection Conference - Weeds, pp.123-132, 2001.

Owen, M. J., Powles, S. B.: Distribution and frequency of herbicide resistant wild oat (Avena spp.) across the western Australian grain belt. Crop Science, 60, 25-31, 2009.

Pacanoski, Z.: The influence of some herbicides on barley depending on growth stages; Master Thesis, Faculty of Agriculture, Skopje, 133 pp., 2003.

Pilipavičius, V.: Herbicides in winter wheat of early growth stages enhance crop productivity, Herbicides properties, synthesis and control of weeds, Dr. Mohammed Nagib Hasaneen (Ed.), ISBN: 978-953-307-803-8, InTech, Available from: http://www.intechopen.com/books/herbicides-properties-synthesis-and-controlof-weeds/herbicides-in-winter-wheat-of-early-growth-stages-enhance-crop-productivity, 2012.

Pilipavičius, V., Aliukoniene, I., Romaneckas, K.: Chemical weed control in winter wheat (Triticum aestivum L.) crop of early stages of development: I. Crop weediness. Journal of Food, Agriculture and Environment, 8 (1), 206-209, 2010.

Qasem, J. R.: Chemical control of wild-oat (Avena sterilis L.) and other weeds in wheat (Triticum durum Desf.) in Jordan. Crop Protection, 26, 1315-1324, 2007.

Ramsey, F. L., Schafer, D. W.: The statistical sleuth: A course in methods of data analysis. Belmont, CA: Duxbury. pp. 91-97, 1997.

Rola, H., Rola, J.: Competition of Apera spica-venti in winter wheat. In the Proceedings of a Conference Held at Brighton, England. Plant Protection for Human Welfare. British Crop Protection Council, Croydon, UK, p.122, 1983. 
Schröder, G., Meinlschmidt, E., Balgheim, R., Bergmann, E., Gössner, K.: Effective control of loose silky-bent (Apera spica-venti (L.) P. B.) in winter cereals using highly efficacious herbicide treatments. Results of comparative trials in the federal states Brandenburg, Hessen, Saxony, Saxony-Anhalt and Thuringia from 2001 to 2011. In the Proceedings of the 25 $5^{\text {th }}$ German Conference on Weed Biology and Weed Control, Braunschweig, Germany, 2012.

Schroeder, D., Mueller-Schaerer, H., Stinson, C. S. A.: A European weed survey in 10 major crop systems to identify targets for biological control. Weed Research, 33, (6), 519-525, 1993.

Sharma, M. P., Vanden Born, W. H.: The biology of Canadian weeds, 27: Avena fatua L. Canadian Journal of Plant Science, 58 (1): 141-157, 1978.

Shehzad, M. A., Maqsood, M., Anwar-ul-Haq, M., Niaz, A.: Efficacy of various herbicides against weeds in wheat (Triticum aestivum L.). African Journal of Biotechnology, 11 (4), 791-799, 2012.

Singh, R. D., Gosh, A. K.: Evaluation of herbicides for control of wild oat (Avena ludoviciana) in wheat (Triticum species). Indian Journal of Agronomy, 37, 327-331, 1992.

Smit, H. A.: Die verdraagsaamheid van wildehawer vir onkruiddoders. PhD (Agric) thesis, University of Free State, South Africa, 1993.

Stankiewicz-Kosyl, M., Wrochna, M., Salas, M., Gawronski, S. W.: A strategy of chemical control of Apera spica-venti L. resistant to sulfonylureas traced on the molecular level. Journal of Plant Protection Research, 57 (2), 113-119, 2017.

Szelezniak, E., Grabinski, J., Nieróbca P.: Weed infestation of three grain species cultivated under cereal crop rotation and three technologies varying in production intensity. Acta Scientiarum Polonorum - Agricultura, 6 (4), 83-90, 2007.

Tanji, A., Boutfirass, M.: Effective preemergence herbicides for rigid ryegrass (Lolium rigidum Gaud.) control in irrigated bread wheat (Triticum aestivum L.). Journal of Agricultural Science, 10 (4), 79-85, 2018.

Thomas, C. G., Yaduraju, N. T.: Comparative growth and competitiveness of winter wild oats (Avena sterilis ssp. ludoviciana) and wheat (Triticum aestivum). Indian Journal of Weed Science, 32, 129-134, 2000.

Tomlin, C. D. S.: The e-pesticide manual: a world compendium. Isoxaben. $13^{\text {th }}$ ed. PC CD-ROM, Version 3.0, 2003-04. Surrey, UK: British Crop Protection Council, 2003.

Tottman, D. R., Ingram, G. H., Lock, A. A., Makepeace, R. J., Orson, J., Smith, J., Wilson, B. J.: Weed control in cereals. In: Weed control handbook: Principles. Roberts, H. A. (Ed.): $7^{\text {th }}$ ed. Blackwell Scientific Publications, Boston Melbourne, pp 268-291, 1982.

Vouzounis, N. A., Americanos, P. G.: Residual activity of linuron and pendimethalin determined by bioassays in field trials. Agricultural Research Institute, Ministry of Agriculture, Natural Resources and the Environment, Nicosia, Cyprus. Technical Bulletin, 169, 3-7, 1995.

Walia, U. S., Brar, L. S.: Competitive ability of wild oats (Avena ludoviciana Dur.) and broad leaf weeds with wheat in relation to crop density and nitrogen levels. Indian Journal of Weed Science, 33, 120-123, 2001.

Weber, R., Sekutowski, T., Owsiak, Z.: Variability of weed infestation of winter wheat cultivars in relation to tillage systems. Progress in Plant Protection, 54 (2), 178-184, 2014.

Wilcut, J. W., York, A. C., Wehtje, G. R.: The control and interaction of weeds in peanut (Arachis hypogaea). Reviews of Weed Science, 177-205, 1994.

$\boldsymbol{W u}, \boldsymbol{H}$., Koetz, E.: Long-term seed bank management of wild oats in southern New South Wales. Plant Protection Quarterly, 29, 143-146, 2014. 


\section{Efikasnost PRE-EM herbicida u suzbijanju travnih korova u usevu ozime pšenice (Triticum aestivum L.)}

\section{REZIME}

Poljski ogledi su izvedeni na dva lokaliteta u ozimoj pšenici tokom dve vegetacione sezone (2013-2014., odnosno 2014-2015.) da bi se ispitala mogućnost mešavine PRE-EM herbicida u suzbijanju travnih korova. Na oba lokaliteta (Bitolj, Probištip) bila je visoka brojnost sledećih korovskih vrsta: Avena ludoviciana Dur., Apera spica-venti (L.) P. Beauv., Milium vernale M. Bieb. i Alopecurus myosuroides Huds. Efikasnost zemljišnih (PRE-EM) herbicida varirala je u zavisnosti od korovske vrste, tretmana, perioda ocenjivanja, lokaliteta i godine. Generalno, ukupna efikasnost primenjenih PRE-EM herbicida je bila u korelaciji sa vremenskim uslovima. U 2013-2014. godini svi PRE-EM tretmani su značajno redukovali brojnost $A$. spica-venti i $M$. vernale, dok u 2014-2015. to nije bio slučaj zbog velikih padavina (68 mm) koje su se javile tokom prve i druge nedelje nakon primene herbicida. Suprotno ovome, na području Podštipa, gde je nakon primene herbicida palo veoma malo kiše, efikasnost primenjenih tretmana je bila nedovoljna u odnosu na A. myosuroides u 2013-2014. godini. Međutim, u 2014-2015. godini, kada je bilo dovoljno padavina, efikasnost zemljišnih herbicida je bila odlična u odnosu na $A$. myosuroides. Četiri nedelje nakon tretiranja (28 DNT) svi PRE-EM herbicidi su ispoljili visoku efikasnost u odnosu na $A$. myosuroides (92-100\%). Visoka efikasnost u odnosu na mačiji rep se zadržala i 150 DNT. Suprotono ovome, svi ispitivani PRE-EM tretmani su ispoljili nedovoljnu efikasnost prema A. ludoviciana (na području Bitolja ona se kretala od 69-63\%, odnosno 49-67\% na području Podštipa tokom obe godine). Razlika u efikasnosti PRE-EM graminicida u odnosu na ove dve travne vrste se može dovesti u vezu sa činjenicom da semena A. ludoviciana veoma često mogu klijati i iz dubljih slojeva zemljišta na koja realno izostaje efekat zemljišnih herbicida, zatim, njihova semena se odlikuju izraženijom dormantnošću i često dolazi do sukcesivnog klijanja i nicanja biljaka.

Ključne reči: PRE-EM herbicidi, travni korovi, padavine. 